\title{
Regional Inequalities in Socio-economic Development in Nassarawa State of Nigeria: A Spatial Analysis for Planning
}

\author{
J. O. Adefila ${ }^{1}$ \\ ${ }^{1}$ Department of Geography, Ahmadu Bello University, Zaria, Nigeria \\ Correspondence: J. O. Adefila, Department of Geography, Ahmadu Bello University, Zaria, Nigeria. Tel: \\ 234-803-830-9791. E-mail: olufila59@gmail.com
}

Received: October 16, 2012 Accepted: November 6, 2012 Online Published: December 31, 2012

doi:10.5539/ass.v9n1p60

URL: http://dx.doi.org/10.5539/ass.v9n1p60

\begin{abstract}
The pattern of development in any region is largely a function of certain processes ranging from socio-cultural, political, historical to environmental resources that are unevenly distributed over space. The study aimed at examining the spatial inequalities in socio-economic development in Nassarawa State with a view to making a comparative analysis of the pattern of development. Large amount of data were generated from socio-economic variables through the administration of seven hundred and eighty questionnaires among the randomly sampled population in the thirteen local government areas. The field survey also witnessed conducting oral interview and collection of secondary data from relevant ministries, bodies and agencies in order to authenticate the data generated from the respondents. The study adopted location quotient (LQ) analytical technique. The finding shows variations in the overall levels of development. The study area is categorized into upper, middle and bottom based on their performance in the distribution of socio-economic facilities. The upper group include Keffi (58), Akwanga (96), Wamba (113) and Nassarawa-Eggon (129) while the middle category is Keana (156), Awe (169), Doma (179) and Nassarawa (195). The bottom group are Obi (197), Lafia (205), Kokona (207), Toto (216) and Karu (217) in that descending order of performance. Indeed, it depicts a core-periphery spatial pattern of development. Although on the aggregate the co-efficient of localization (0.14) appears to be low, it should not be misconstrued for a balanced development. On the basis of findings, one recommends among other things that communal self-help projects should be encouraged in each area by embarking on building of schools, colleges and health centres. Also, the cooperative movements particularly at community levels can go a long way to solving financial predicaments of the under-privileged and disadvantaged areas. The government can embark upon discriminatory investments in socio-economic activities in favour of the lagging areas with a view to promoting social justice and balanced development not only in the study area but also in Nigeria at large.
\end{abstract}

Keywords: inequalities, economic development, spatial analysis, planning

\section{Introduction}

\subsection{Introduction to the Research Problem}

It is glaring that socio-economic activities are spatially spread unevenly. The reason is that certain factors ranging from historical, political, cultural, natural endowment to economic processes often produce regional differences. With understanding of processes at work, attempts have always been made towards the identification of spatial variations among the regions and to produce a body of theory for their areal explanation. However, the description of the regional disparities is not enough, but further attempts should be made geared towards the analysis of the societal problems arising from environmental contrasts and to proffer lasting solutions involving rational planning.

Indeed, the phenomenon of spatial inequality is widely recognized as major characteristics of developing countries particularly in Nigeria. Morenikeji (2000) remarked that inequality is epitomized in the use of terms such as "advantaged and disadvantaged" Adefila (2008) added other terms to include "privileged and under-privileged" to describe areas that are either comparatively well-off or lagging behind in certain attributes. On the global scene, spatial inequality among countries is approached by categorizing the countries into "developed and under-developed" "advanced and developing" "rich and poor" countries. Inequalities are most glaring between the commercial, rich and industrial urban centres on the one hand and extensive poor, agricultural and rural areas on the other hand. The former are generally better provided with both quality and 
quantity of all the good things of life such as pipe-borne water, electricity, education, good roads and job opportunities at the expense of the rural majority. For this reason, Olatunbosun (1995) concluded that Nigeria neglected rural majority. It is obvious that there is wide gap in socio-economic development between rural and urban areas not only in Nigeria but also in the developing countries. Saraceno (1995) remarked that the poor quality of the rural environment contributed to the 'push factor' in the mobility of rural population to few urban centres thereby, compounding the problems of both source and destination of the migrants.

The social policy of a just and egalitarian society connotes a fair-play and social justice in the distribution of essential goods and services among the regions irrespective of the location, tribe, political affiliation and origin and was entrenched in the Second National Development Plan (Nigeria, 1970:32) has not been strictly implemented. However, the focus of this study is to examine the level of spatial balance in socio-economic development and undertake a comparative analysis of the spatial pattern of development among the thirteen local government areas of Nassarawa State.

\subsection{Conceptual Framework of Study}

The concept of economic development is fundamental to the understanding of this study. The term growth is often used interchangeably with development but in a strict sense, economic growth relates to the aggregate substantial increase in national output and material improvement in the economy (Jhingan, 2000). It is the increase in the Gross Domestic Product (GDP) or the real per capita income. However, the concept of economic development is quite broader and embracing because it involves not only growth but also structural, socio-cultural, technological and attitude changes in our value systems. Some social scientists (Omoleke, 2000; Mba, 1995; Adefila, Todaro, 2000) have drawn our attention to the drawbacks of employing income per capita as a measure of economic development. The reason is that the income per capita for a country may be high yet the wealth is much concentrated in the hands of privileged individuals without filtering to the poor masses at the community levels. World Bank (2001) quoted Cote D'Ivoire as having $\$ 640$ per capita as opposed to Nigeria having \$240 per capita. Although the former may be ranked higher in terms of economic growth, the latter is far ahead in terms of economic development. The reason is that in Nigeria, there is a high degree of indigenous participation in the control of the political and economic life. In effect, it is possible to experience economic growth without development.

Seers (1969) underscored certain questions to be answered affirmatively in understanding the concept of development. The questions related to the extent of abject poverty, unemployment and spatial inequality. If two out of these economic problems have reduced from high to lower levels then, it marked a period of development for the country. But if they are on the increase, it is strange to call it development even if the per capita of the country is more than doubled. Todaro and Smith (2011) identified three core values of development namely, sustenance, self-esteem and freedom. Sustenance has to do with ability to meet the basic needs such as food, clothing, shelter, education and health care, self-esteem relates to recognition of worthiness, self-respect and not to be used as tool by others for their egocentric interests and freedom related to emancipation from alienating material conditions of life and from social servitude to nature, misery and oppression. Moreover, development must be viewed in a multi-dimensional process involving changes in techniques, structural attributes and institutions. Oyugi (2000) had earlier remarked that economic development should be associated with increases in per capita income, social well-being, reduction in unemployment as well as spatial inequality.

\subsection{Studies in Socio-economic Development-An Overview}

An extensive and intensive academic research had been conducted in socio-economic development in the developed, developing countries as well as in Nigeria. Falola (1999) examined spatial inequalities in Nigeria's social services such as health care and education variables as surrogates to measure level of development in Nigeria. The location quotient (LQ) techniques that was employed to analyse the data revealed that the variables particularly health facilities were localized in few urban centres. Rotimi (1994) adopted standardized score (Z-score) approach to investigate the spatial variations in socio-economic facilities in Kwara State, Nigeria and discovered that some districts such as Ilorin, Omu-aran, Offa and others were at advantaged while other areas like Patigi, Lafiagi, Kiama and others were disadvantaged.

Ogunsanya (2002) remarked in his inaugural lecture that transport was analogous to internal organs of human body that often worked as the life-wire of our socio-economic and political life. Transportation is considered as an indispensable factor in any regional economic growth and development. In addition, availability of efficient and effective financial institutions such as commercial banks, community banks, post office savings and insurance agencies are crucial to rapid economic growth (Familoni, 2001; Adefila, 2008). The Central Bank Governor of Nigeria, Sanusi (2010) had remarked that the country needs to embark upon people-oriented 
programmes such as agriculture and small scale businesses that can positively impact on the condition of living of the masses and as such can reduce the spatial inequalities among the rural and urban areas. Indeed, low capital accumulation has been identified as a potent obstacle to regional economic development as level of consumption is much higher than level of savings thus, leading to vicious circle of indebtedness especially in the developing countries (Todaro, 2000). One may add that it not just capital accumulation that inhibit rapid socio-economic development but also political instability, corruption arising from siphoning public funds and vicissitudes in foreign exchange earnings that can mar implementation and execution of goal directed programmes.

Umoh (2002) assessed the impact of rural electricity and roads as facilitators of socio-economic development of rural areas in Kaura Namoda, Zamfara State and revealed that recent installation of rural electricity supply and construction of access roads has increased volume of investments in areas of transport services and which has contributed immensely to economic growth in the study area.

Having reviewed some studies in socio-economic development, it is glaring that the tempo of research in this regard is still low or absent as far as Nassarawa State is concerned. It thus becomes imperative to fill this gap in research and it could be used as a case study to visualize the level of spatial balance in socio-economic development in this country.

\subsection{Research Questions}

The study endeavours to address the following research questions and they include:-

1) What is the level of spatial balance with respect to socio-economic development in the study area?

2) Why is the polarized pattern of development in the study area?

3) What should government do to reduce spatial inequalities in the study area in particular and in Nigeria at large?

\section{Method}

This section deals with aspects of approach adopted in this study. It includes the choice of criteria, sources of data, sample size, data collection procedure and the analytical technique.

\subsection{Choice of Criteria}

There is always a problem of deciding the indicators of economic growth and development arising from the divergence of opinions regarding its definition. There are re-definitions from time to time to reflect the thinking of modern social scientists and to keep in line with the new millennium development goals. World Bank (1997; Todaro and Smith 2011) highlighted some indicators of development. However, in this study twenty four variables have been carefully selected in consonance with what is obtainable in the study area. The list of the indicators is presented in Table 1.

Table 1. Indicators of development

\begin{tabular}{llll}
\hline S/No & Variable & S/No. & Variable \\
\hline & Income per capita & 13. & Maternity beds/thousand \\
2. & Primary school enrolment & 14. & Medical doctors \\
3 & Primary school female enrolment & 15. & Nurses and midwives \\
4 & Primary school teacher-pupil ratio & 16. & Chemists/Pharmacists \\
5. & Primary school teachers & 17. & Post Office boxes \\
6. & Secondary school enrolment & 18. & Access road (Km) \\
7. & Secondary school female enrolment & 19 & Financial institutions \\
8. & Secondary school student-teacher ratio & 20 & Water consumption/day \\
9. & Secondary school teachers & 21. & Electricity $(\mathrm{MGW)/ \text {area }}$ \\
10. & Adult education enrolment & 22. & Cooperative societies \\
11. & Adult education instructors & 23 & Social organizations \\
12. & Hospital beds & 24. & Community development \\
\hline
\end{tabular}

Source: Author

We need to remind ourselves that the indicators in this study are by no means exhaustive. This is not deliberate but largely due to dearth of data in certain areas. For instance, data on the number of unemployed persons, agricultural outputs, and people with radios, television set, video and a host of others were not included. 


\subsection{Sources of Data and Collection Procedure}

The study employed a well-structured questionnaire to collect relevant data from the respondents in the thirteen local government areas of Nassarawa State. A sample of seven hundred and eighty (780) was taken to reflect the population of the people in the study area. In addition, oral interview was conducted among the people at the community levels as well

\subsection{Technique of Data Analysis}

In this study, the location quotient (LQ) approach was adopted because of its simplicity and elegance which made it popular among the regional analysts (Morenikeji, 1995; and Falola, 1999; World Bank, 2006). The location quotient is used to measure socio-economic conditions based on per capita distribution of physical, social, economic and infrastructural facilities. The location quotient is expressed as:

\section{$\underline{\mathrm{S}} / \underline{\mathrm{S}}$ \\ $\mathrm{N}_{\mathrm{i}} / \mathrm{N}$}

Where: $S_{i}=$ the number of a variable in a unit area (LGA)

$\mathrm{S}=$ the total number of that variable in the region (State)

$\mathrm{N}_{\mathrm{i}}=$ the number of people in a unit area

$\mathrm{N}=$ the total number of people in the region

This statistical technique helps to measure the relative regional concentration of a given socio-economic facility as compared to some regional aggregate. The coefficient was derived by calculating each unit area's percentage share of the regional (State) population and its percentage share of each of the socio-economic variables. The differences between the percentage population and share of the parameters are obtained. The localization coefficient value is derived by taking the sum of the negative and positive scores for each variable for all the unit areas (LGAs) and the value is divided by 100 . The coefficient of localization ranges from zero to unity with zero indicating an even distribution of the facility and unity indicating that such facility is localized.

In order to produce the spatial pattern of socio-economic development in the study area, the unit areas are ranked according to their performance in a descending order in each of the variables. The sum of the ranks is taken for all the unit areas. The decision rule here is that the lower the sum of ranks, the better the performance. However, the major pitfall of this approach is that it neither fails to depict intra-local government disparities nor takes cognisance of difference in scale say, a cottage hospital or a Teaching hospital.

\section{Results}

A cursory look at Table 2, it presents the location quotient values for the thirteen local government areas (LGAs) in Nassarawa State. The analysis reveals that the major urban areas in the State namely Toto, Doma and Lafia did not rank among the first category of developed areas. This fact becomes obvious when the number of facilities is related to the number of people served. It thus means that socio-economic facilities in those areas are inadequate for the teeming population. It is discovered that developed areas within the upper third comprise Keffi (58), Akwanga (96), Wamba (113) and Nassarawa-Eggon (129). The least developed areas at the bottom third include Obi (197), Lafia (205), Kokona (207), Toto (216), and Karu (217) in that descending order of performance.

Table 2. Nassarawa state: Local government areas by LQ values

\begin{tabular}{|c|c|c|c|c|c|c|c|c|c|c|c|c|c|}
\hline LGA & Keffi & Akwanga & Wamba & $\begin{array}{l}\text { Nass. } \\
\text { Eggon }\end{array}$ & Keana & Awe & Doma & Nassarawa & Obi & Lafia & Kokona & Toto & Karu \\
\hline LQ 1 & 1.76 & 1.27 & 3.41 & 1.25 & 3.05 & 1.38 & 1.05 & 0.47 & 0.76 & 0.16 & 1.42 & 1.07 & 0.6 \\
\hline LQ 2 & 0.02 & 0.02 & 0.03 & 0.03 & 0.01 & 0.01 & 0.01 & 0.01 & 1.8 & 0.01 & 0.01 & 0.01 & 0.01 \\
\hline LQ 3 & 0 & 2.83 & 0.01 & 0.01 & 3.55 & 2.45 & 0 & 2.93 & 2.8 & 0 & 0 & 0 & 0 \\
\hline LQ 4 & 1.58 & 1.06 & 2.53 & 1.89 & 1.54 & 1.73 & 1.53 & 0.53 & 0.78 & 0.46 & 1.29 & 0.58 & 0.46 \\
\hline LQ 5 & 1.08 & 1.43 & 2.09 & 1.34 & 1.31 & 0.61 & 0.66 & 1.34 & 0.99 & 0.6 & 0.56 & 1.29 & 1.03 \\
\hline LQ 6 & 4.55 & 1.51 & 0.6 & 1.39 & 0.29 & 1.99 & 0.82 & 0.91 & 0.16 & 0.71 & 0.54 & 0.05 & 0.93 \\
\hline LQ 7 & 3.91 & 1.66 & 0.58 & 1.65 & 0.48 & 1.72 & 1.13 & 0.95 & 0.18 & 0.52 & 0.46 & 0.06 & 1.26 \\
\hline LQ 8 & 2.48 & 1.12 & 2.7 & 0.93 & 1.48 & 1.54 & 0.85 & 0.64 & 0.63 & 0.38 & 2.18 & 0.31 & 0.99 \\
\hline LQ 9 & 3 & 1.93 & 0.57 & 1.96 & 0.41 & 1.65 & 1.04 & 1.07 & 0.25 & 0.77 & 0.34 & 0.2 & 0.79 \\
\hline
\end{tabular}




$\begin{array}{llllllllllllll}\text { LQ 10 } & 2.07 & 3.22 & 1.93 & 2.23 & 0.53 & 1.11 & 0.32 & 0.88 & 0.85 & 0.26 & 1.1 & 0.14 & 1.07 \\ \text { LQ 11 } & 2.28 & 1.75 & 1.63 & 2.42 & 0.84 & 0.85 & 0.43 & 1.31 & 0.7 & 0.23 & 0.66 & 0.68 & 1.35 \\ \text { LQ 12 } & 1.95 & 1.7 & 0.27 & 1.56 & 0.4 & 0.31 & 1.26 & 1.64 & 1.18 & 0.91 & 0.19 & 1.28 & 0.1 \\ \text { LQ 13 } & 1.13 & 1.04 & 1.27 & 0.85 & 0.93 & 0.81 & 0.87 & 0.36 & 0.55 & 2 & 0.81 & 0.84 & 0.44 \\ \text { LQ 14 } & 2.34 & 1.03 & 0.92 & 1.94 & 0 & 0.92 & 1.17 & 0.56 & 0.7 & 1.62 & 0 & 0.79 & 0.3 \\ \text { LQ 15 } & 3.08 & 1.35 & 1.67 & 1.18 & 0.7 & 0.84 & 0.79 & 0.62 & 0.82 & 1.02 & 0.59 & 0.8 & 0.72 \\ \text { LQ 16 } & 2.27 & 1.99 & 0.89 & 0.47 & 0.75 & 0.9 & 1.14 & 0.81 & 1.02 & 0.72 & 0-94 & 1.16 & 0.86 \\ \text { LQ 17 } & 1.85 & 1.82 & 1.24 & 1.41 & 1.62 & 0.86 & 1.64 & 0.45 & 0.83 & 0.89 & 0.76 & 0.79 & 0.39 \\ \text { LQ 18 } & 2.03 & 0.91 & 3.11 & 1.05 & 2.52 & 1.28 & 0.73 & 0.77 & 0.79 & 0,09 & 1.51 & 1.56 & 0.77 \\ \text { LQ 19 } & 2.37 & 1.82 & 1.86 & 0.99 & 2.35 & 0.47 & 0.99 & 0.85 & 0.36 & 0.75 & 0.74 & 0.8 & 0.99 \\ \text { LQ 20 } & 2.24 & 1.11 & 1.59 & 0.81 & 0.46 & 0.8 & 0.76 & 0.73 & 1.2 & 0.91 & 1.2 & 1.04 & 0.9 \\ \text { LQ 21 } & 1.25 & 0.57 & 0.88 & 1 & 0.74 & 0.71 & 1.01 & 2.05 & 0.91 & 1.3 & 0.43 & 0.5 & 0.52 \\ \text { LQ 22 } & 2.42 & 1.12 & 1.22 & 0.56 & 3.06 & 0.63 & 0.54 & 0.94 & 1.27 & 1.03 & 0.7 & 0.38 & 0-62 \\ \text { LQ 23 } & 2.14 & 2.35 & 0.58 & 1.33 & 2.11 & 0.34 & 0.64 & 1.17 & 0.64 & 0.84 & 1.07 & 0.58 & 0.59 \\ \text { LQ 24 } & 2.14 & 1.6 & 1.32 & 0.65 & 1.88 & 0.82 & 1.17 & 1.08 & 0.7 & 0.66 & 0.92 & 1.15 & 0-62 \\ \text { Sum of } & 58 & 96 & 113 & 129 & 156 & 169 & 179 & 195 & 197 & 205 & 207 & 216 & 217 \\ \text { Rank } & & & & & & & & & & & & & \end{array}$

Source: Author

The analysis of the indicators takes a four dimensional approach namely, economic, health, infrastructure and social. The result revealed that economic development at the aggregate level in the study area is not localized but fairly distributed. The coefficient of localization of the parameters of development is presented in Table 3 .

The economic dimension shows that income per capita has a coefficient of $(0.18)$, education dimension has mean coefficient of (0.12), health care dimension (0.13), infrastructure (0.15) and social organization (0.15). This result confirms the relatively fair distribution of economic development facilities in the study area. A glance at the primary school enrolment in the state with coefficient value of 0.01 suggests that the study area is heading towards an evenly distributed primary education. Considering the health care dimension, the coefficient of 0.13 on the aggregate is indicative of a reasonable degree of development in the area of health care facilities.

Table 3. Coefficient of localization of the variables

\begin{tabular}{|c|c|c|}
\hline $\mathrm{S} / \mathrm{No}$ & Indicators of Development & Coefficient Value \\
\hline & Economic Dimension:- & \\
\hline \multirow[t]{3}{*}{1.} & Income per capita & 0.18 \\
\hline & Mean $=$ & 0.18 \\
\hline & Education Dimension:- & \\
\hline 2. & Primary school enrolment & 0.01 \\
\hline 3. & Primary school female enrolment & 0.15 \\
\hline 4. & Primary school teacher-student ratio & 0.16 \\
\hline 5. & Primary school teachers & 0.14 \\
\hline 6. & Secondary school enrolment & 0.14 \\
\hline 7. & Secondary school female enrolment & 0.15 \\
\hline 8. & Secondary school student-teacher ratio & 0.16 \\
\hline 9. & Secondary school teachers & 0.14 \\
\hline 10. & Adult education enrolment & 0.16 \\
\hline \multirow[t]{2}{*}{11.} & Adult education instructor & 0.15 \\
\hline & Mean $=$ & 0.14 \\
\hline
\end{tabular}


Health Care Dimension:-

12.

Hospital beds

13. Maternity beds

14. Medical doctors

0.12

15. Nurse and midwives

16.

Chemists and pharmacists

Mean $=$

Infrastructural Dimension:-

17. Post office boxes

18. Access road (Km.)

19.

Commercial banks and financial institutions

20. Water consumption/day

21.

Electricity consumption (MGW)/Unit area

Mean $=$

Social Dimension:-

22. Cooperative societies

23.

Social clubs and organizations

Community development

Mean $=$

Aggregate Mean =

Source: Author

However, this may not be true to intra-local government inequalities in health care distribution even among the highest ranked areas. The pattern of distribution in respect of the infrastructural facilities with a coefficient of 0.15 epitomized a fair distribution of the facilities in the study area. The distribution of social organization is widespread. The cooperatives, social clubs and community development on the aggregate has a coefficient of 0.14. Indeed, Nassarawa State can be described as a land of cooperative per excellence. On the overall development pattern, except for Toto that is located at a distant, developed areas are compact and concentrated in the central part of the State. However, the under-developed areas such as Karu, Keana and Kokona are farther apart and the distance decay effect must have contributed to their levels of development.

\section{Discussion and Implication for Planning}

In this study, there are some policy and planning implications for socio-economic development in the study area in particular and in the country at large. The spatial pattern of development shows that certain areas are somehow under-privileged in terms of development. It therefore suggests that resources could be harnessed to create premises around which policy could be directed with a view to promoting social justice in the distribution of socio-economic facilities. There are observable variations in the overall levels of development in the study area as in many of the States in Nigeria. Although the study did not show much about the localization of the socio-economic facilities, this situation report should not be misconstrued for a balanced development. The true position is that spatial imbalance among States and local government areas continue to exist.

It is important for the physical and economic planners to cooperate. While the economic planner allocates the resources for specific projects, the physical planner should be allowed to choose the optimal location of such projects NITP, (1997). By so doing, the incidence of localization of economic facilities in the few urban centres would no longer arise. In addition, it will go a long way to stem the tide of population mobility from rural to urban areas.

Perhaps a possible direction is the promotion of community development as a strategy through self-help projects such as building of schools, colleges, hospitals, health centers and community banks in order to reduce the community over-dependence on the government. It is obvious that the government cannot provide all the basic needs of the society but it could give technical and financial assistance to community that embark upon self-help projects as it contained in the Second National Development Plan (1970-74). The trust here is that, by so doing each locality will have increased accessibility to socio-economic facillities irrespective of locations. 
There should be discriminatory investments in small-scale industries and small business enterprises in favour of lagging areas. The non-governmental organizations (NGOs) and other private agencies can become partners in progress with the government in this direction. In this regard, one applauds the Federal Government in employing the private sector as engine of economic growth but it should be done with caution.

The role of producer co-operative movement at the community levels cannot be over-emphasized. The Thrift and Credit co-operative societies should be promoted and supported by the government through legislative control. Indeed, financial grants in form of cash flow from these co-operatives to the members remain very high. The credit facilities that are made available to members are found to be judiciously expended on executing projects such as building residential houses, purchase of vehicles, trading and commercial activities, poultry and fisheries projects (Adefila, 2012), only to mention a few of them.

\section{Concluding Remarks}

The study shows that some areas have the socio-economic facilities more than their average shares and this singular factor explains the edge they have over other areas. If the results in this study are to be reckoned with, then the government should be more serious about the policy statement of establishing an egalitarian society. It connotes a social justice and fair- play without discrimination against religion, political affiliation, historical origin and tribe. Indeed, every citizen in this country must have access to necessities of life such as housing, health care, adequate food, quality education and improved quality of life.

If Nigeria has anything to do with the eight-agenda of the Millennium Development Goals (MDGs), by now there should be manifestations of moving towards a balanced development, eradication of abject poverty and improved infrastructure. To the best of one's assessment, the country like other countries in Africa, are far from achieving the laudable millennium goals within the stipulated period of year 2015!

It is expected that government at all levels (Federal, State and Local) should collaborate with affluent and advanced countries of the world in order to induce them to embark upon large scale investments in lagging regions in Nigeria. The philanthropists, the non-governmental organizations (NGOs) both nationally and internationally should not be left behind in the struggle towards emancipating this country from socio-economic backwardness.

\section{Acknowledgements}

First and foremost, one is most grateful to the Vice Chancellor, Ahmadu Bello University, Zaria, Nigeria who gave financial assistance for online publications. Also, to my class-mates namelt, Bako, Madaki, 'Demokun and Jones that rendered invaluable services to me on the field while collecting the data. I am indebted to the Manager, Iludun-Oro Microfinance Bank, Kwara State who generously made credit facilities available to me at critical times. It worth mentioning the cooperation received from Commissioners of various ministries and Accountants who magnanimously released classified documents to me. The computer section, of the University of Ilorin that helped in coding and analyzing the data. Equally important is the Ministry of Land and Survey, Lafia that assisted me with topographical and political maps of Nassarawa State, Nigeria. The Librarians of the University of Ilorin and Kashim Ibrahim Library, Ahmadu Bello University, Zaria who permitted me to consult books, documented materials and official gazettes. The typing of the manuscript was done by my humble self.

\section{References}

Adefila, J. O. (2006). Spatial dimension of inequalities in infrastructure development in Plateau State, Nigeria. Journal of International Research and Development Studies. Uyo. Kan Educational Books.

Adefila, J. O. (2008). Understanding economic growth and development in Nigeria: The relevance of core-periphery spatial inequality theory. Sahel Analyst, Journal of the Faculty of social and management sciences, 10(1), 86-95.

Adefila, J. O. (2012). Spatial assessment of farmers' cooperative organizations in agricultural development in Gurara area of Niger State, Nigeria. Journal of Ecology and the Natural Environment (JENE), 4(2), 51-57. Retrieved from http://www.academicjournals.org/jene

Adefila, J. O. (2012). The challenge of bottom-up paradigm and popular participation in rural economic development of Nigeria: The way forward. International Journal of Asian_Social Sciences (IJASS), 2(8), 1286-1293. Retrieved from http://www.aessweb.com/journal-detail.php?id=5007

Falola, J. A. (1999). Spatial inequality in Nigeria's social services. In Swindell, K. (Ed.), inequalities and development: Case studies from the third world countries. Macmillan, London. 
Familoni, J. A. (2001). Community banking and infrastructural imperative to grassroot development. Case study of rural areas of Ekiti State. Conference proceedings on rural environment and sustainable development in Nigeria. University of Ado-Ekiti.

Federal Republic of Nigeria. (n. d.). Second National Development Plan (1970-74:32). Government Printer. Lagos.

Jhingan, M. L. (2000). The economics of development and planning (2nd ed.). Vrinda publications. Delhi. India.

Mba, H. C. (1995). Introduction to rural development planning. Computer edge publications. Enugu.

Morenikeji, W. (1995). Spatial pattern of development in Ondo State: An inter-local government area analysis. Journal of economic and social studies, 37(1), 41-45.

Morenikeji, W. (2000). Dimension of development pattern in Nigeria. A spatial analysis. African Journal of social and policy studies, 1(2), 144-145.

Nigerian Institute of Town Planners (NITP). (1997). Bulletin of NITP, 30 ${ }^{\text {th }}$ anniversary. pp.7-8.

Ogunsanya, A. A. (2002). Maker and breaker of cities. The fifty-ninth inaugural lecture. University of Ilorin. Ilorin.

Olatunbosun, D. (1995). Nigeria neglected rural majority. NISER, Ibadan.

Omoleke, I. I. (2000). Planning with grassroots: A socio-economic development strategy. African Journal of social and policy studies, 1(1), 153-161.

Oyugi, W. O. (2000). Decentralization for good governance and development. The unending debate. Regional Development Dialogue (RDD), 21(1), 3-24.

Rotimi, D. A. (1994). Regional socio-economic inequality in Kwara State, Nigeria: A spatial analysis in development planning. Unpublished Ph.D. Thesis. Department of Geography. University of Ilorin. Ilorin.

Sanusi, L. S. (2010, November). Growth prospects for the Nigeria's economy. Eighth Convocation lecture delivered at the Igbinedion University. Okada. Edo State.

Saraceno, E. (1995). Recent trends in rural development and their conceptualization. Journal of rural studies. Elsevies sciences. 10(4), 321-335. http://dx.doi.org/10.1016/0743-0167(94)90042-6

Seers, D. (1969). The meaning of development. Eleventh world conference of the society for international development. Delhi. India.

Todaro, M. P. (2000). Economics for the developing countries. New York, Wiley press.

Todaro, M. P., \& Smith, S. C. (2011). Economic development (11th ed.). Pearson Education. Edinburgh. England.

Umoh, E. A. (2002). Infrastructural and socio-economic development in sahelian Nigeria. The case study of Kaura Namoda. African Journal of social and policy studies, 1(2), 247-250.

World Bank. (2001). African development indicator. Washington.

World Bank. (2006). Where is the wealth of nations? Measuring capital for the $21^{\text {st }}$ century. Washington DC. World Bank. 